\title{
Prospect of vasoactive intestinal peptide therapy for COPD/PAH and asthma: a review
}

Dongmei $\mathrm{Wu}^{1,2^{*}}$, Dongwon Lee ${ }^{2}$ and Yong Kiel Sung ${ }^{3}$

\begin{abstract}
There is mounting evidence that pulmonary arterial hypertension (PAH), asthma and chronic obstructive pulmonary disease (COPD) share important pathological features, including inflammation, smooth muscle contraction and remodeling. No existing drug provides the combined potential advantages of reducing vascular- and bronchialconstriction, and anti-inflammation. Vasoactive intestinal peptide (VIP) is widely expressed throughout the cardiopulmonary system and exerts a variety of biological actions, including potent vascular and airway dilatory actions, potent anti-inflammatory actions, improving blood circulation to the heart and lung, and modulation of airway secretions. VIP has emerged as a promising drug candidate for the treatment of cardiopulmonary disorders such as PAH, asthma, and COPD. Clinical application of VIP has been limited in the past for a number of reasons, including its short plasma half-life and difficulty in administration routes. The development of long-acting VIP analogues, in combination with appropriate drug delivery systems, may provide clinically useful agents for the treatment of PAH, asthma, and COPD. This article reviews the physiological significance of VIP in cardiopulmonary system and the therapeutic potential of VIP-based agents in the treatment of pulmonary diseases.
\end{abstract}

\section{Introduction}

Vasoactive intestinal peptide (VIP) is a 28 -amino-acid peptide, which was first isolated from upper intestine, and has been characterized as a vasodilatory peptide [1]. VIP has a very widespread distribution in the central and peripheral nervous systems [2]. It is one of the most abundant neuropeptides found in the cardiovascular system and airways [2-5]. This neuropeptide exerts a wide range of biological actions, such as positive inotropic and chronotropic effects, pulmonary and coronary vasodilatation, bronchodilation, and anti-inflammatory effects, and thus it influences many aspects of cardiopulmonary function [6-8]. Studies using VIP deficient animals and using animal models of diseases have indicated that VIP has significant therapeutic potential in the treatment of cardiopulmonary diseases, including pulmonary arterial hypertension (PAH), chronic obstructive pulmonary disease (COPD) and asthma [9-11].

\section{Clinical manifestation of PAH}

$\mathrm{PAH}$ is a disabling chronic disorder of the pulmonary vasculature, which is characterized by abnormal

\footnotetext{
* Correspondence: dongmeiwu@bellsouth.net

'Department of Research, Mount Sinai Medical Center, Miami Beach, FL 33140, USA

Full list of author information is available at the end of the article
}

pulmonary vascular proliferation and remodeling, vasoconstriction, perivascular inflammation, and thrombosis, leading to elevated pulmonary arterial pressure, increases in peripheral vascular resistance, and it ultimately results in right heart failure and death $[12,13]$. The past two decades have seen significant advances with the development and clinical implementation of a number of medications for the treatment of PAH: prostanoids, endothelin-1 receptor antagonists, and phosphodiesterase type 5 inhibitors. However, the results remain unsatisfactory, with persistent high mortality, insufficient clinical improvement and no convincing report of any reversal of the disease process $[12,13]$. In addition, the current PAH therapy requires a cocktail of drugs to manage PAH symptoms and often leads to drug intolerance [14]. Therefore, it is necessary to develop additional novel therapeutic approaches that target the various components of this multifactorial disease. VIP provides the combined potential advantages of lowering pulmonary arterial pressure, improving blood circulation to the heart and lung, reducing inflammation of the heart and lung tissues, and is readily accepted by the body because it is natural to it [1-8]. Based on its multiple biological actions, the development of controlled release airway drug-delivery system with VIP has 
emerged as a novel therapeutic strategy for the treatment of PAH.

\section{Clinical manifestation of COPD and asthma}

Chronic inflammatory airway diseases such as bronchial asthma or COPD are major contributors to the global burden of disease. COPD is characterized by a chronic, slowly progressive airway disorder resulting from a combination of pulmonary emphysema and irreversible reduction in the caliber of the small airways of the lung, resulting in airflow limitation [15]. Asthma is a complex, persistent, inflammatory disease characterized by airway hyperresponsiveness in association with airway inflammation. Although there are many allopathic treatments, including bronchodilators and corticosteroids, there is no single medication that is effective against both the inflammatory and bronchoconstrictive components of asthma [16]. VIP exerts functions not only as a vasodilator and bronchodilator but also as a potent immunomodulator $[1,7,8]$, thus VIP has significant therapeutic potential in the treatment of pulmonary diseases, including: $\mathrm{PAH}$, asthma and COPD. However, VIP-based drugs are not yet in clinical use, possibly because the poor metabolic stability and difficulty in administration routes. The development of long-acting VIP analogues, in combination with appropriate drug delivery systems, may provide clinically useful agents for the treatment of $\mathrm{PAH} /$ asthma/COPD. This article reviews the physiological significance of VIP in cardiopulmonary system and the therapeutic potential of VIP-based agents in the treatment of pulmonary diseases.

\section{Expression and distribution of VIP in cardiovascular-pulmonary system}

VIP is co-localized with acetylcholine in postganglionic parasympathetic neurons in the cardiovascular and respiratory systems [17]. In the mammalian heart, VIP was found in nerve fibers associated with atrial and ventricular myocardium, conduction system, and coronary vessels [18-21]. Immunofluorescent and radioimmunoassay studies have localized VIP to neuronal cell bodies of the intrinsic cardiac ganglia, axons and dendrites, and presynaptic nerve terminals from which VIP is released as a nonadrenergic-noncholinergic neurotransmitter [22]. In the peripheral nervous system, VIP is present in sympathetic ganglia, the vagus nerves, some motor nerves such as the sciatic nerve, autonomic nerves that supply exocrine glands, vascular and nonvascular smooth muscle, and ganglion-like clusters of neuronal cell bodies that provide 'intrinsic' organ innervation $[18,23]$.

VIP is abundantly present in normal human lungs $[1,2,24]$. VIP-immunoreactivity (IR)-containing cells are present in the tracheobronchial smooth muscle layer and glands of airways, and within the walls of pulmonary and bronchial vessels $[25,26]$. VIP-IR nerve fibers are found as branching networks in the respiratory tract [4]. The frequency of these VIP-ergic fibers decreases as the airways become smaller, and only a few VIP-ergic fibers are present in bronchioles and alveolar space [26]. The pattern of VIP-ergic nerve fiber distribution largely follows that of cholinergic nerves, which is consistent with the colocalization of VIP with acetylcholine [27]. VIP is also co-localized with nitric oxide synthase (NOS) in human and guinea-pig airways [28-30]. In human airways, a colocalized immunoreactivity of VIP and NOS is found in airway intrinsic neuronal perikarya $[28,30]$. Furthermore, VIP has also been identified in some sensory nerves, including sub-epithelial airway nerves [27,31]; as well as in immune cells such as mast cells [32], eosinophils $[33,34]$, and in different mononuclear cells and polymorphonuclear leukocytes [35]. A deficiency of VIP in the respiratory system is considered to be a pathogenetic factor in pulmonary disease [36,37].

\section{VIP release and metabolism}

Circulating VIP in men is found in low plasma levels. However, an increase in plasma concentration has been detected in conditions, such as gastrointestinal stimulation, during strenuous exercise, acute myocardial infarction and gastrointestinal tumors [38-41]. Circulating VIP is produced from VIP-containing nerve fibers. Many VIP-containing nerves have a perivascular distribution and it thus seems likely that VIP can exert important local effects without producing a detectable increase in systemic levels [42]. Myocardial blood vessels and also pulmonary blood vessels are innervated by VIP immunoreactive nerve fibers, which cause vascular smooth muscle dilation $[18,23]$. Endogenous VIP is released by high frequency nerve stimulation and also is released by neostigmine, as well as by serotonin, dopaminergic agonists such as bromocriptine and apomorphine, prostaglandins (PGE, PGD) and nerve growth factor $[43,44]$.

Under physiological conditions, VIP is mainly cleaved by endopeptidase, whereas in states of airway inflammation, mast cell enzymes dominate the degradation of VIP [45-47]. VIP is readily degraded by enzymes, including neutral endopeptidase, mast cell-derived tryptase and chymase, thus preventing it from relaxing vascular or tracheal smooth muscle [45-47].

\section{VIP receptors in cardiovascular-pulmonary system}

The biological effects of VIP are mediated by two type II G-protein-coupled receptors: VPAC1 and VPAC2 [48]. Stimulation of VPAC receptors by VIP causes dosedependent activation of adenylate cyclase, which increases cAMP concentrations, and activates cAMPand cGMP-dependent protein kinases and leads to 
smooth muscle relaxation via decreasing intracellular calcium levels [49]. While VIP binds both VPAC1 and VPAC2 receptors with high affinity, VIP can also bind with low affinity to the pituitary adenylate cyclase activating peptide (PACAP) receptor. PACAP is another secretin family member peptide that exhibits extensive similarities to VIP and shares VIP receptors and functions [50].

High densities of VIP binding sites were found in the pulmonary vascular smooth muscle layer and in airway smooth muscle of large, but not smaller airways. VIP binding sites are also present in sub-mucosal glands, airway epithelium and in alveolar walls [24,51]. In the human upper respiratory tract, VIP receptors were found on submucosal glands, epithelial cells, and arterial but not sinusoidal vessels [5]. VIP receptors are also expressed in innate immune cell types, including human mast cells, neutrophils, and peripheral blood monocytes, and murine macrophages and dendritic cells [52-56]. VIP is thought to play a role in regulating immunity and inflammation. Studies using VPAC2 receptor knockout mice and transgenic mice overexpressing the VPAC2 receptor have revealed that the receptor regulates the balance between T-helper type 1 and 2 lymphocytes (Th1 and Th2 cells) by stimulating production of more Th2-type cytokines, which mediate hypersensitivity reactions (e.g. allergy) $[57,58]$. Thus, this receptor is believed to play an important functional role in the respiratory tract by regulation of immune effects of VIP in allergic diseases such as allergic bronchial asthma.

The wide spread presence of VIP receptors in a variety of tissues and organ systems has led to the potential limitation of its clinical application. Intravenous administration of VIP has been shown to ameliorate histamine-induced bronchoconstriction in asthmatic subjects; while it also caused cardiovascular side effects by decreasing systemic blood pressure, inducing tachycardia and cutaneous flushing [59]. Thus, the development of effective drug delivery systems with airway delivery capability for VIP-based respiratory therapy represents a possible therapeutic strategy.

\section{Role of VIP in heart and blood vessels}

VIP is a potent vasodilator in coronary and pulmonary blood vessels, as well as other systemic blood vessels. The presence of VIP nerve fibers and their receptors in the coronary and pulmonary arteries strongly suggests that this peptide is important in the regulation of cardiopulmonary blood flow. VIP induces endothelium-independent relaxation in most of the vascular beds, including cat cerebral artery, dog isolated carotid artery, pig coronary artery, and bovine pulmonary artery [3-6].

There is direct evidence that VIP acts on heart muscle in various experimental system. VIP exerts a primary positive inotropic effect on cardiac muscle. In dogs, VIP infusion increases cardiac contractility and improves ventricular-vascular coupling, thus VIP enhances delivery of mechanical energy from the LV to the circulatory bed [60]. In isolated atrial or ventricular muscle, VIP, increases developed isometric force and is greater than isoproterenol in enhancing ventricular muscle contractile force [61]. VIP also exerts a primary positive chronotropic effect in the heart. Injection of VIP directly into the dog sinoatrial artery increases heart rate by $37 \%$, VIP also dose-dependently shortens the atrioventricular conduction time, decreases the atrial and ventricular refractory periods [61,62]. Endogenously released VIP increases atrial and ventricular contractility, and heart rate. Stimulation of the parasympathetic (vagal) nerves, during muscarinic and $\beta$-adrenergic receptor blockade in dogs, increases the atrial contractile force by $32 \%$, increases heart rate by $37 \%$, and also increases right ventricular contraction and relaxation by 28 and 33\%, respectively $[63,64]$. In patients with acute myocardial infarction, the VIP concentration in the plasma may increase by $33-62 \%$ within $6 \mathrm{~h}$ of the onset of symptoms [41]. Upon acute coronary ischemia, VIP is released from neurons in the coronary vessels and myocardium, and may also be released from the splanchnic viscera, and can act as a vasodilator to reduce myocardial ischemia $[18,65]$.

\section{Biological actions of VIP in airway}

VIP is a potent vasodilator of airway smooth muscle in vitro and in vivo. In isolated tracheal or bronchial segments, VIP attenuates the constrictor effect of histamine, prostaglandine $\mathrm{F} 2 \alpha$, endothelin, leukotriene D4, kallikrein and neurokinin A $[66,67]$. The bronchodilatory effect of VIP in human bronchi is almost 100 times more potent than adrenergic dilatation by isoproterenol, and VIP is the most potent endogenous bronchodilator described so far [68]. VIP is also involved in the regulation of airway mucus secretion. High density VIPexpressing nerve fibers and VPAC2 mRNA have been found in airway submucosal glands [25,69]. The role of VIP in airway mucus secretion has been controversial. VIP has been shown to have both stimulation and inhibition effects on airway secretion. In the human trachea, VIP inhibited methacholine-stimulated release of glycoproteins and lysozyme [70]. In the upper airways, VIP was shown to stimulate lactoferrin secretion from human nasal mucosal cells, but had little effects on mucous glycoprotein release [71]. VIP inhibits cholinergic secretion in ferret trachea, whereas it stimulates cholinergic secretion in the cat trachea [72,73]. Therefore, the importance of VIP in airway mucus secretion appears to differ from species to markers examined. Future studies using human tissue and cells need to be 
performed in order to further elucidate the role of VIP on mucus secretion that associated with hypersecretory diseases such as COPD or asthma.

\section{VIP in inflammatory response}

Progressive pulmonary inflammation is the hallmark of airway diseases, including asthma, COPD and PAH. VIP has been shown to exert immunomodulating and antiinflammatory activities through VIP specific receptors [74]. VIP inhibits the release of mediators from pulmonary mast cells, interacts with $\mathrm{T}$ lymphocytes, prevents lung injury due to xanthine oxidase and may act as a free radical scavenger [75-78]. VIP also inhibits the production of IL-6, IL-12, TNF alpha, and nitric oxide, and stimulates IL-10 production, and these effects are mostly mediated through the constitutively expressed VPAC1 receptor at the transcriptional level via modulation of $\mathrm{NF} \kappa \mathrm{B}$ and cAMP responsive element (CRE)-binding or ets-2 complexes [79]. Dunzendorfer et al. have suggested that VIP has an anti-inflammatory effect on eosinophils, reporting that VIP inhibited eosinophil migration and production of IL-16 in vitro, which subsequently inhibited chemotaxis of lymphocytes [80,81]. Delgado et al. also reported that VIP inhibited LPSinduced inflammatory pathways in monocytes and macrophages via cAMP-dependent or independent mechanisms [55]. In addition, it has been suggested that VIP functions as an important $\mathrm{T}$ helper-differentiating factor that promotes Th2-like and inhibits Th1-like immune response via several mechanisms, including preferential survival of Th2 effectors and generation of memory Th2 cells [82]. In vitro studies show that VIP treatment leads to the induction of IL-4 and IL-5 in macrophages, and leads to the inhibition of IFN-gamma and IL-2 in antigen-primed CD4 T cells [83]. Mice lacking VPAC2 showed increased Th1-type responses which were characterized by an enhanced delayed type hypersensitivity and a diminished immediate-type hypersensitivity [58] In contrast, T cell over-expression of VPAC2 led to a deviation from the normal CD4 T cell cytokine expression profile toward a Th2-like profile with elevated blood IgE and IgG1 levels and increased eosinophil numbers. These transgenic mice also showed increased cutaneous allergic reactions, and a decreased delayed-type hypersensitivity [58]. Future study should further examine the immune-regulatory role of VIP using animal models with $\mathrm{T}$ cell-related diseases such as allergic asthma.

\section{Therapeutic potential of VIP in PAH}

The main pathological features of PAH in the pulmonary vasculature are perivascular inflammation, thrombosis, abnormal growth of vascular smooth muscle cells and extracellular matrix accumulation, leading to remodeling of the pulmonary vessel wall, obstruct pulmonary blood flow and ultimately cause right heart failure. Current treatment of PAH, which includes the use of prostacyclins, endothelin receptor antagonists, and phosphodiesterase type 5 inhibitors, either alone or in combination, have only limited efficacy in the improvement of clinical symptoms, hemodynamics, and longterm survival [12-14]. VIP has a large spectrum of biological functions including potent dilatory actions in pulmonary blood vessels and airway smooth muscles, potent anti-inflammatory actions, inhibition of vascular smooth muscle cell proliferation, enhancing would healing, regulation of cell growth and survival, and modulation of airway secretions. Therefore, using VIP-based drugs to target the various components of this multifactorial disease could be a novel therapeutic approach for the treatment of PAH.

In monocrotaline-induced pulmonary hypertension in rabbits, VIP dose-dependently decreased pulmonary artery pressure and pulmonary vascular resistance [83]. Application of VIP to patients with primary pulmonary hypertension results in substantial improvement of hemodynamic and prognostic parameters of the disease without side effects [36]. It decreased the mean pulmonary artery pressure in these patients, increased cardiac output, and mixed- venous oxygen saturation [36]. Said indicated that VIP gene is a key modulator of pulmonary vascular remodeling and inflammation [84]. Mice lacking VIP gene developed moderately severe PAH, with right ventricular hypertrophy, and thickened pulmonary artery, as well as perivascular inflammatory cell infiltrates in the lung [85]. Treatment of the mice with VIP attenuated both the vascular remodeling and right ventricular remodeling [85]. Right heart failure is a hallmark of severe PAH, and ultimately leading to death. In animals and in humans, infusion of VIP increases the epicardial coronary artery cross-sectional area by $27 \%$, decreases coronary vascular resistance by $46 \%$, and increases coronary artery blood flow by $200 \%[20,86]$. Application of VIP to patients also increases the left ventricular fraction shortening by $38 \%$ and significantly increases left ventricular contractility [86,87]. Therefore, addition to its actions on decreasing pulmonary artery pressure, VIP also protects the heart.

\section{Therapeutic potential of VIP in COPD/asthma}

Chronic inflammatory airway diseases such as COPD and bronchial asthma continue to be an important cause of morbidity, mortality, and health-care cost worldwide. The key clinical features of asthma are airflow obstruction and airway hyperresponsiveness that caused by airway inflammation [16]. Many of the inflammatory events in asthma are thought to be mediated by Th2 cells. It also involves mast cells, 
eosinophils, neutrophils and mesenchymal cells such as epithelial cells, fibroblasts, smooth muscle cells and endothelial cells. The inflammatory mediators, including cytokines, chemokines, adhesion molecules, proteinases and growth factors released by these cells participant in this process at various stages and interact to maintain and amplify the inflammatory response [11]. Two categories of drugs are currently used in asthma therapies: bronchodilators and anti-inflammatory drugs. Despite the availability of these medications, the asthma epidemic continues to increase. The key clinical feature of COPD is airflow limitation results from airway constriction and irreversible reduction in the caliber of the small airways of the lung. Cigarette smoking is an important risk factor of COPD. The airflow limitation or obstruction that happens in COPD is caused by a mixture of small airway disease, parenchymal destruction (emphysema) and in many cases, increased airway responsiveness (asthma) [15]. Studies have shown that there is a large overlap of up to $30 \%$ between people who have a clinical diagnosis of COPD and asthma [88]. There is also a high incidence of mild to moderate $\mathrm{PAH}$ prevalence, reaching to $50 \%$ in advanced chronic obstructive COPD [89]. As Said suggested that PAH/ asthma/COPD share important pathological features, including inflammation, smooth muscle contraction and remodeling [90]. Inflammation has long been acknowledged as a key feature of the asthma and COPD $[11,15,16,88,89]$. Perivascular inflammation has also been increasingly recognized as a significant component of clinical and experimental PAH phenotypes [91]. In these diseases there is increased resistance in, and narrowing of, airways and pulmonary arteries, respectively, due to airway and pulmonary vasoconstriction, smooth muscle constriction, and thickening of the walls caused by smooth muscle and other cell proliferation known as remodeling [90]. Muscularisation and remodeling of smaller pulmonary arteries are essential pathological lesions in PAH [92]. Airway remodeling caused by airway inflammation includes an increase in airway wall thickness, fibrosis, smooth muscle mass and vascularity, as well as abnormalities in extracellular matrix composition $[89,93]$. These shared pathological features suggest possible common underlying mechanism among PAH/ asthma/COPD.

Mice with targeted deletion of VIP gene, simultaneously express airway hyperresponsiveness with airway inflammation, together with $\mathrm{PAH}$, pulmonary vascular remodeling and perivascular inflammation. Treatment of the mice with VIP reversed both sets of phenotypic changes, confirming that they result from the absence of the VIP gene $[10,84]$. Recently, attention has been drawn to the therapeutic potential of VIP for the clinical treatment of COPD/asthma on the basis that VIP acts as a neurotransmitter, the dominant mechanism of human airway and vascular relaxation, and its anti-inflammatory properties. Neutrophil accumulation in the airway is a characteristic feature of COPD and asthma. VIP and its analogues have been shown to inhibit antigen- or cytokine-induced neutrophil recruitment in the airway in vivo [94]. VIP has also been shown to attenuate the cigarette smoke extract-induced apoptotic death of rat alveolar L2 cells, and protect against human bronchial epithelial cell damage, enhance airway wound healing $[95,96]$. Recent studies show that inhalable powder formulation of VIP derivative, IK312532 attenuates airway inflammation in ovalbumin challenge-induced asthma/ COPD -like rats and in cigarette smoke-exposed rats $[9,97,98]$.

\section{VIP for clinical use}

The key to the therapeutic use of VIP in human disease is in its delivery. Firstly, VIP is degraded quickly by enzymes, catalytic antibodies, and spontaneous hydrolysis in biological fluids. Secondly, systemic administration of VIP has been shown to cause cardiovascular side effects [59]. To overcome the limited clinical effectiveness of native VIP, VIP incorporated into phospholipids has been used successfully in animal models of pulmonary hypertension [99]. Furthermore, several peptidaseresistant VIP-analogues have been developed [100]. VIP analogue, Ro 25-1553 causes a concentration-dependent relaxation of airway and pulmonary artery preparations, with an EC50 of approximately $10 \mathrm{nM}$ and a maximal relaxation of $70 \%-75 \%$ of the induced tone [101]. In patients with asthma, inhalation of a selective VPAC2 receptor agonist Ro 25-1553 causes a bronchodilatory effect. The corresponding maximum bronchodilatory effect during 24 hours was similar for Ro 25-1553 and the reference bronchodilator formoterol (beta-2 adrenoceptor agonist). However, the bronchodilatory effect of Ro 25-1553 was attenuated 5 hours after inhalation whereas formoterol still had a bronchodilatory effect 12 hours after inhalation [102]. Therefore, the development of effective drug delivery systems for VIP-based respiratory therapy remains a significant challenge. It is possible to envisage that development of controlled-release biodegradable VIP-based drug system, particularly with airway delivery capability would have very significant therapeutic benefits in the treatment of cardiopulmonary diseases, including PAH, COPD and asthma.

\section{Conclusion}

This article describes the physiological significance of VIP and its therapeutic potential for the treatment of cardiopulmonary diseases, including $\mathrm{PAH}$, asthma, and COPD. VIP exerts a variety of actions, including potent dilatory actions in pulmonary blood vessels and airway 
smooth muscles, potent anti-inflammatory and anti-proliferative actions, regulation of cell growth and survival, and modulation of airway secretions. $\mathrm{PAH}$, asthma and COPD share key mechanisms of pathogenesis, including inflammation, smooth muscle contraction and remodeling. No other existing or potential drug provides the combined potential advantages of lowering pulmonary arterial pressure, reducing bronchoconstriction, improving blood circulation to the heart and lung, reducing inflammation of the heart and lung tissues, and enhancing wound healing of bronchial epithelial cells. Therefore, development of drug delivery system for VIP-based respiratory therapy may be a promising strategy for the treatment of PAH, asthma and COPD.

\section{List of abbreviations}

VIP: vasoactive intestinal peptide; VIP-IR: VIP-immunoreactivity; PAH: pulmonary arterial hypertension; COPD: chronic obstructive pulmonary disease; PACAP: pituitary adenylate cyclase activating peptide; VPAC1: VIP/ PACAP receptor type1; VPAC2: VIP/PACAP receptor type 2; NOS: nitric oxide synthase; CRE: CAMP responsive element.

\section{Acknowledgements}

This work was supported in part by the World Class University program (R31-20029) funded by the Ministry of Education, Science and Technology", Republic of Korea.

\section{Author details}

'Department of Research, Mount Sinai Medical Center, Miami Beach, FL 33140, USA. ${ }^{2}$ WCU program, Department of BIN Fusion Technology, Chonbuk National University, Korea. ${ }^{3}$ ReSEAT Program, KISTI, 206-9 Cheongnyangni-dong, Dongdaemun-gu, Seoul 130-742, Korea; Department of Chemistry, Dongguk University, Phil-dong, Chung-gu, Seoul 100-715, Korea.

\section{Authors' contributions}

All authors participated in drafting the manuscript. All authors read and approved the manuscript.

\section{Competing interests}

The authors declare that they have no competing interests.

Received: 4 February 2011 Accepted: 11 April 2011

Published: 11 April 2011

\section{References}

1. Said SI, Mutt V: Polypeptide with broad biological activity: isolation from small intestine. Science 1970, 169:1217-8.

2. Said SI: Vasoactive intestinal peptide. J Endocrinol Invest 1986, 9:191-200.

3. Said SI, Mutt V, Yoshida T, Hara N: Vasoactive polypeptides from normal lung. Chest 1975, 67:44S.

4. Ghatei MA, Sheppard MN, O'Shaughnessy DJ, Adrian TE, McGregor GP, Polak JM, Bloom SR: Regulatory peptides in the mammalian respiratory tract. Endocrinology 1982, 111:1248-54.

5. Baraniuk JN, Lundgren JD, Okayama M, Mullol J, Merida M, Shelhamer JH, Kaliner MA: Vasoactive intestinal peptide in human nasal mucosa. $J$ Clin Invest 1990, 86:825-31.

6. Dvoráková MC: Cardioprotective role of the VIP signaling system. Timely Top Med Cardiovasc Dis 2005, 9:E33.

7. Saga T, Said SI: Vasoactive intestinal peptide relaxes isolated strips of human bronchus, pulmonary artery, and lung parenchyma. Trans Assoc Am Physicians 1984, 97:304-10.

8. Smalley SG, Barrow PA, Foster N: Immunomodulation of innate immune responses by vasoactive intestinal peptide (VIP): its therapeutic potential in inflammatory disease. Clin Exp Immunol 2009, 157:225-34.
9. Onoue S, Misaka S, Aoki Y, Karaki S, Kuwahara A, Ohide A, Mizumoto T, Yamada S: Inhalable powder formulation of vasoactive intestinal peptide derivative, [R15,20,21, L17]-VIP-GRR, attenuated neutrophilic airway inflammation in cigarette smoke-exposed rats. Eur J Pharm Sci 2010 41:508-14.

10. Szema AM, Hamidi SA, Lyubsky S, Dickman KG, Mathew S, Abdel-Razek T, Chen JJ, Waschek JA, Said SI: Mice lacking the VIP gene show airway hyperresponsiveness and airway inflammation, partially reversible by VIP. Am J Physiol Lung Cell Mol Physiol 2006, 291:L880-6.

11. Onoue S, Yamada S, Yajima T: Bioactive analogues and drug delivery systems of vasoactive intestinal peptide (VIP) for the treatment of asthma/COPD. Peptides 2007, 28:1640-50.

12. Yuan JX, Rubin L: Pathogenesis of pulmonary arterial hypertension: the need for multiple hits. Circulation 2005, 111:534-8.

13. Gandhi R, Baker N, Shek A, Yeh J, Bishop D: Pulmonary arterial hypertension: bridging the gap between efficacy, quality of life, and cost-effectiveness. Formulary 2010, 45:190-199.

14. Sahara M, Takahashi T, Imai $Y$, Nakajima T, Yao A, Morita T, Hirata Y, Nagai R: New insights in the treatment strategy for pulmonary arterial hypertension. Cardiovasc Drugs Ther 2006, 20:377-86.

15. Mannino DM, Buist AS: Global burden of COPD: risk factors, prevalence, and future trends. Lancet 2007, 370:765-73.

16. Berger WE, Cline DC: Asthma and COPD: definitions, epidemiology, and treatment guidelines. Postgrad Med 2005, 118:2-8.

17. Lundberg JM: Pharmacology of cotransmission in the autonomic nervous system: integrative aspects on amines, neuropeptides, adenosine triphosphate, amino acids and nitric oxide. Pharmacol Rev 1996, 48:113-78.

18. Henning RJ, Sawmiller DR: Vasoactive intestinal peptide: cardiovascular effects. Cardiovasc Res 2001, 49:27-37.

19. Della NG, Papka RE, Furness JB, Costa M: Vasoactive intestinal peptide-like immunoreactivity in nerves associated with the cardiovascular system of guinea-pigs. Neuroscience 1983, 9:605-19.

20. Brum JM, Bove AA, Sufan Q, Reilly W, Go VL: Action and localization of vasoactive intestinal peptide in the coronary circulation: evidence for nonadrenergic, noncholinergic coronary regulation. J Am Coll Cardiol 1986, 7:406-13.

21. Slavíková J: Distribution of peptide-containing neurons in the developing rat right atrium, studied using immunofluorescence and confocal laser scanning. Neurochem Res 1997, 22:1013-21.

22. Kuncová J, Slavíková J, Reischig J: Distribution of vasoactive intestinal polypeptide in the rat heart: effect of guanethidine and capsaicin. Ann Anat 2003, 185:153-61.

23. Fahrenkrug J: VIP and autonomic neurotransmission. Pharmacol Ther 1989 41:515-34

24. Groneberg DA, Rabe KF, Fischer A: Novel concepts of neuropeptide-based drug therapy: vasoactive intestinal polypeptide and its receptors. Eur J Pharmacol 2006, 533:182-94.

25. Dey RD, Shannon WA Jr, Said SI: Localization of VIP-immunoreactive nerves in airways and pulmonary vessels of dogs, cat, and human subjects. Cell Tissue Res 1981, 220:231-8.

26. Lundberg JM, Fahrenkrug J, Hökfelt T, Martling CR, Larsson O, Tatemoto K, Anggård $\mathrm{A}$ : Co-existence of peptide $\mathrm{HI}(\mathrm{PHI})$ and VIP in nerves regulating blood flow and bronchial smooth muscle tone in various mammals including man. Peptides 1984, 5:593-606.

27. Laitinen A, Partanen M, Hervonen A, Pelto-Huikko M, Laitinen LA: VIP like immunoreactive nerves in human respiratory tract. Light and electron microscopic study. Histochemistry 1985, 82:313-9.

28. Fischer A, Hoffmann B: Nitric oxide synthase in neurons and nerve fibers of lower airways and in vagal sensory ganglia of man. Correlation with neuropeptides. Am J Respir Crit Care Med 1996, 154:209-16.

29. Fischer A, Canning BJ, Undem BJ, Kummer W: Evidence for an esophageal origin of VIP-IR and NO synthase-IR nerves innervating the guinea pig trachealis: a retrograde neuronal tracing and immunohistochemical analysis. J Comp Neurol 1998, 394:326-34.

30. Fischer A, Canning BJ, Kummer W: Correlation of vasoactive intestinal peptide and nitric oxide synthase with choline acetyltransferase in the airway innervation. Ann N Y Acad Sci 1996, 805:717-22.

31. Luts A, Sundler F: Peptide-containing nerve fibers in the respiratory tract of the ferret. Cell Tissue Res 1989, 258:259-67.

32. Cutz E, Chan W, Track NS, Goth A, Said SI: Release of vasoactive intestinal polypeptide in mast cells by histamine liberators. Nature 1978, 275:661-2. 
33. Aliakbari J, Sreedharan SP, Turck CW, Goetzl EJ: Selective localization of vasoactive intestinal peptide and substance $P$ in human eosinophils. Biochem Biophys Res Commun 1987, 148:1440-5.

34. Metwali A, Blum AM, Ferraris L, Klein JS, Fiocchi C, Weinstock JV: Eosinophils within the healthy or inflamed human intestine produce substance P and vasoactive intestinal peptide. J Neuroimmunol 1994, 52:69-78.

35. O'Dorisio MS, O'Dorisio TM, Cataland S, Balcerzak SP: Vasoactive intestinal polypeptide as a biochemical marker for polymorphonuclear leukocytes. J Lab Clin Med 1980, 96:666-72.

36. Petkov V, Mosgoeller W, Ziesche R, Raderer M, Stiebellehner L, Vonbank K, Funk GC, Hamilton G, Novotny C, Burian B, Block LH: Vasoactive intestinal peptide as a new drug for treatment of primary pulmonary hypertension. J Clin Invest 2003, 111:1339-46.

37. Haberl I, Frei K, Ramsebner R, Doberer D, Petkov V, Albinni S, Lang I, Lucas T, Mosgoeller W: Vasoactive intestinal peptide gene alterations in patients with idiopathic pulmonary arterial hypertension. Eur J Hum Genet 2007, 15:18-22.

38. Opstad PK: The plasma vasoactive intestinal peptide (VIP) response to exercise is increased after prolonged strain, sleep and energy deficiency and extinguished by glucose infusion. Peptides 1987, 8:175-8.

39. Burhol PG, Lygren I, Waldum HL: Radioimmunoassay of vasoactive intestinal polypeptide in plasma. Scand I Gastroenterol 1978, 13:807-13

40. Bloom SR, Polak JM, Pearse AG: Vasoactive intestinal peptide and waterydiarrhoea syndrome. Lancet 1973, 2:14-6.

41. Gyöngyösi M, Németh J, Várkonyi T: Elevated levels of plasma vasoactive intestinal peptide in human acute myocardial infarction. Int J Cardiol 1996, 56:159-61.

42. Domschke S, Domschke W, Bloom SR, Mitznegg P, Mitchell SJ, Lux G, Strunz U: Vasoactive intestinal peptide in man: pharmacokinetics, metabolic and circulatory effects. Gut 1978, 19:1049-53.

43. Lundberg JM, Fahrenkrug J, Brimijoin S: Characteristics of the axonal transport of vasoactive intestinal polypeptide (VIP) in nerves of the cat. Acta Physiol Scand 1981, 112:427-36.

44. Said SI: Vasoactive intestinal polypeptide (VIP): current status. Peptides $1984,5: 143-50$

45. Goetzl EJ, Sreedharan SP, Turck CW, Bridenbaugh R, Malfroy B: Preferential cleavage of amino- and carboxyl-terminal oligopeptides from vasoactive intestinal polypeptide by human recombinant enkephalinase (neutral endopeptidase, EC 3.4.24.11). Biochem Biophys Res Commun 1989, 158.850-4

46. Caughey GH, Leidig F, Viro NF, Nadel JA: Substance P and vasoactive intestinal peptide degradation by mast cell tryptase and chymase. $J$ Pharmacol Exp Ther 1988, 244:133-7.

47. Lilly CM, Kobzik L, Hall AE, Drazen JM: Effects of chronic airway inflammation on the activity and enzymatic inactivation of neuropeptides in quinea pig lungs. J Clin Invest 1994, 93:2667-74.

48. Laburthe M, Couvineau A: Molecular pharmacology and structure of VPAC Receptors for VIP and PACAP. Regul Pept 2002, 108:165-173.

49. Francis $\mathrm{SH}$, Noblett BD, Todd BW, Wells JN, Corbin JD: Relaxation of vascular and tracheal smooth muscle by cyclic nucleotide analogs that preferentially activate purified cGMP-dependent protein kinase. Mol Pharmacol 1988, 34:506-17.

50. Arimura A: Perspectives on pituitary adenylate cyclase activating polypeptide (PACAP) in the neuroendocrine, endocrine, and nervous systems. Jpn J Physiol 1998, 48:301-31.

51. Carstairs JR, Barnes PJ: Visualization of vasoactive intestinal peptide receptors in human and guinea pig lung. J Pharmacol Exp Ther 1986, 239:249-255.

52. Kulka M, Sheen CH, Tancowny BP, Grammer LC, Schleimer RP: Neuropeptides activate human mast cell degranulation and chemokine production. Immunology 2008, 123:398-410

53. Harfi I, D'Hondt S, Corazza F, Sariban E: Regulation of human polymorphonuclear leukocytes functions by the neuropeptide pituitary adenylate cyclase-activating polypeptide after activation of MAPKs. $J$ Immunol 2004, 173:4154-63.

54. Lara-Marquez ML, O'Dorisio MS, Karacay B: Vasoactive intestinal peptide (VIP) receptor type 2 (VPAC2) is the predominant receptor expressed in human thymocytes. Ann NY Acad Sci 2000, 921:45-54.

55. Delgado M, Munoz-Elias EJ, Gomariz RP, Ganea D: Vasoactive intestinal peptide and pituitary adenylate cyclase-activating polypeptide prevent inducible nitric oxide synthase transcription in macrophages by inhibiting NF-kappa B and IFN regulatory factor 1 activation. J Immunol 1999, 162:4685-96

56. Delneste Y, Herbault N, Galea B, Magistrelli G, Bazin I, Bonnefoy JY, Jeannin P: Vasoactive intestinal peptide synergizes with TNF-alpha in inducing human dendritic cell maturation. J Immunol 1999, 163:3071-5.

57. Goetzl EJ, Voice JK, Shen S, Dorsam G, Kong Y, West KM, Morrison CF, Harmar AJ: Enhanced delayed-type hypersensitivity and diminished immediate-type hypersensitivity in mice lacking the inducible VPAC2 receptor for vasoactive intestinal peptide. Proc Natl Acad Sci USA 2001, 98:13854-13859.

58. Voice JK, Grinninger C, Kong Y, Bangale Y, Paul S, Goetzl EJ: Roles of vasoactive intestinal peptide (VIP) in the expression of different immune phenotypes by wild-type mice and T cell-targeted type II VIP receptor transgenic mice. J Immunol 2003, 170:308-314.

59. Morice A, Unwin RJ, Sever PS: Vasoactive intestinal peptide causes bronchodilatation and protects against histamine-induced bronchoconstriction in asthmatic subjects. Lancet 1983, 2:1225-7.

60. Colston JT, Freeman GL: Beneficial influence of vasoactive intestinal peptide on ventriculovascular coupling in closed-chest dogs. Am J Physiol 1992, 263:H1300-5.

61. Rigel DF, Grupp IL, Balasubramaniam A, Grupp G: Contractile effects of cardiac neuropeptides in isolated canine atrial and ventricular muscles. Am J Physiol 1989, 257:H1082-7.

62. Rigel DF, Lathrop DA: Vasoactive intestinal polypeptide facilitates atrioventricular nodal conduction and shortens atrial and ventricular refractory periods in conscious and anesthetized dogs. Circ Res 1990, 67:1323-33.

63. Henning RJ: Vagal stimulation during muscarinic and beta-adrenergic blockade increases atrial contractility and heart rate. J Auton Nerv Sys 1992, 40:121-9.

64. Henning RJ, Feliciano L, Coers CM: Vagal nerve stimulation increases right ventricular contraction and relaxation and heart rate. Cardiovasc Res 1996, 32:846-53

65. Lucia P, Caiola S, Coppola A, Maroccia E, Belli M, Buongiorno A, De Martinis C: Early increase of vasoactive intestinal peptide in acute myocardial infarction. Am Heart J 1996, 132:187-9.

66. Groneberg DA, Springer J, Fischer A: Vasoactive intestinal polypeptide as mediator of asthma. Pulm Pharmacol Ther 2001, 14:391-401.

67. Hamasaki Y, Saga T, Mojarad M, Said SI: Vasoactive intestinal peptide counteracts leukotriene D4-induced contractions of guinea pig trachea, lung, and pulmonary artery. Trans Assoc Am Physicians 1983, 96:406-11.

68. Palmer JB, Cuss FM, Barnes PJ: VIP and PHM and their role in nonadrenergic inhibitory responses in isolated human airways. $J$ App Physiol 1986, 61:1322-8.

69. Groneberg DA, Hartmann P, Dinh QT, Fischer A: Expression and distribution of vasoactive intestinal polypeptide receptor VPAC(2) mRNA in human airways. Lab Invest 2001, 81:749-55.

70. Coles SJ, Said SI, Reid LM: Inhibition by vasoactive intestinal peptide of glycoconjugate and lysozyme secretion by human airways in vitro. Am Rev Respir Dis 1981, 124:531-6.

71. Baraniuk JN, Lundgren JD, Okayama M, Mullol J, Merida M, Shelhamer JH, Kaliner MA: Vasoactive intestinal peptide in human nasal mucosa. J Clin Invest 1990, 86:825-31.

72. Webber SE, Widdicombe JG: The effect of vasoactive intestinal peptide on smooth muscle tone and mucus secretion from the ferret trachea. $\mathrm{Br}$ J Pharmacol 1987, 91:139-48.

73. Shimura S, Sasaki T, Ikeda K, Sasaki H, Takishima T: VIP augments cholinergic-induced glycoconjugate secretion in tracheal submucosal glands. J Appl Physiol 1988, 65:2537-44.

74. Delgado M, Abad C, Martinez C, Juarranz MG, Arranz A, Gomariz RP, Leceta J: Vasoactive intestinal peptide in the immune system: potential therapeutic role in inflammatory and autoimmune diseases. $J \mathrm{Mol}$ Med 2002, 80:16-24

75. Undem BJ, Dick EC, Buckner CK: Inhibition by vasoactive intestinal peptide of antigen-induced histamine release from guinea-pig minced lung. Eur J Pharmacol 1983, 88:247-50.

76. O'Dorisio MS, Shannon BT, Fleshman DJ, Campolito LB: Identification of high affinity receptors for vasoactive intestinal peptide on human lymphocytes of B cell lineage. J Immunol 1989, 142:3533-6. 
77. Berisha H, Foda H, Sakakibara H, Trotz M, Pakbaz H, Said SI: Vasoactive intestinal peptide prevents lung injury due to xanthine/xanthine oxidase. Am J Physiol 1990, 259:L151-5.

78. Misra BR, Misra HP: Vasoactive intestinal peptide, a singlet oxygen quencher. J Biol Chem 1990, 265:15371-4

79. Leceta J, Gomariz RP, Martinez C, Abad C, Ganea D, Delgado M: Receptors and transcriptional factors involved in the anti-inflammatory activity of VIP and PACAP. Ann N Y Acad Sci 2000, 921:92-102.

80. Dunzendorfer S, Meierhofer C, Wiedermann CJ: Signalling in neuropeptideinduced migration of human eosinophils. J Leukoc Biol 1998, 64:828-34.

81. Dunzendorfer S, Feistritzer C, Enrich B, Wiedermann CJ: Neuropeptideinduced inhibition of IL-16 release from eosinophils. Neuroimmunomodulation 2002, 10:217-23, 2003.

82. Delgado M: VIP: a very important peptide in T helper differentiation. Trends Immunol 2003, 24(5):221-4.

83. Gunaydin S, Imai Y, Takanashi Y, Seo K, Hagino I, Chang D, Shinoka T: The effects of vasoactive intestinal peptide on monocrotaline induced pulmonary hypertensive rabbits following cardiopulmonary bypass: a comparative study with isoproteronol and nitroglycerine. Cardiovasc Surg 2002, 10:138-45.

84. Said SI: The vasoactive intestinal peptide gene is a key modulator of pulmonary vascular remodeling and inflammation. Ann N Y Acad Sci 2008, 1144:148-53.

85. Said SI, Hamidi SA, Dickman KG, Szema AM, Lyubsky S, Lin RZ, Jiang YP, Chen JJ, Waschek JA, Kort S: Moderate pulmonary arterial hypertension in male mice lacking the vasoactive intestinal peptide gene. Circulation 2007, 115:1260-8.

86. Popma JJ, Smitherman TC, Bedotto JB, Eichhorn EJ, Said SI, Dehmer GJ: Direct coronary vasodilation induced by intracoronary vasoactive intestinal peptide. J Cardiovasc Pharmacol 1990, 16:1000-6.

87. Frase LL, Gaffney FA, Lane LD, Buckey JC, Said SI, Blomqvist CG, Krejs GJ: Cardiovascular effects of vasoactive intestinal peptide in healthy subjects. Am J Cardiol 1987, 60:1356-61.

88. Soriano JB, Davis KJ, Coleman B, Visick G, Mannino D, Pride NB: The proportional Venn diagram of obstructive lung disease: two approximations from the United States and the United Kingdom. Chest 2003, 124:474-81.

89. Zakynthinos E, Daniil Z, Papanikolaou G, Makris D: Pulmonary Hypertension in COPD: Pathophysiology and Therapeutic Targets. Curr Drug Targets 2011, 12:501-13

90. Said SI, Hamidi SA, Gonzalez BosC L: Asthma and pulmonary arterial hypertension: do they share a key mechanism of pathogenesis? Eur Respir J 2010, 35:730-4

91. Dorfmüller P, Perros F, Balabanian K, Humbert M: Inflammation in pulmonary arterial hypertension. Eur Respir J 2003, 22:358-63.

92. Stenmark KR, Mecham RP: Cellular and molecular mechanisms of pulmonary vascular remodeling. Annu Rev Physiol 1997, 59:89-144.

93. Homer RJ, Elias JA: Airway remodeling in asthma: therapeutic implications of mechanisms. Physiology (Bethesda) 2005, 20:28-35.

94. Sergejeva S, Hoshino H, Yoshihara S, Kashimoto K, Lötvall J, Lindén A: A synthetic VIP peptide analogue inhibits neutrophil recruitment in rat airways in vivo. Regul Pept 2004, 117:149-54.

95. Onoue S, Ohmori Y, Endo K, Yamada S, Kimura R, Yajima T: Vasoactive intestinal peptide and pituitary adenylate cyclase-activating polypeptide attenuate the cigarette smoke extract-induced apoptotic death of rat alveolar L2 cells. Eur JBiochem 2004, 271:1757-67.

96. Guan CX, Zhang M, Qin XQ, Cui YR, Luo ZQ, Bai HB, Fang X: Vasoactive intestinal peptide enhances wound healing and proliferation of human bronchial epithelial cells. Peptides 2006, 27:3107-14.

97. Misaka S, Aoki Y, Karaki S, Kuwahara A, Mizumoto T, Onoue S, Yamada S: Inhalable powder formulation of a stabilized vasoactive intestinal peptide (VIP) derivative: anti-inflammatory effect in experimental asthmatic rats. Peptides 2010, 31:72-8.

98. Misaka S, Sato H, Aoki Y, Mizumoto T, Onoue S, Yamada S: Novel vasoactive intestinal peptide derivatives with improved stability protect rat alveolar L2 cells from cigarette smoke-induced cytotoxicity and apoptosis. Peptides 2011, 32:401-7.

99. Rubinstein I: Human VIP-alpha: an emerging biologic response modifier to treat primary pulmonary hypertension. Expert Rev Cardiovasc Ther 2005 3:565-9.
100. Bolin DR, Cottrell J, Garippa R, Rinaldi N, Senda R, Simko B, O'Donnell M: Comparison of cyclic and linear analogs of vasoactive intestinal peptide. Drug Des Discov 1996, 13:107-14.

101. Schmidt DT, Rühlmann E, Waldeck B, Branscheid D, Luts A, Sundler F, Rabe KF: The effect of the vasoactive intestinal polypeptide agonist Ro 25-1553 on induced tone in isolated human airways and pulmonary artery. Naunyn Schmiedebergs Arch Pharmacol 2001, 364:314-20.

102. Lindén A, Hansson L, Andersson A, Palmqvist M, Arvidsson P, Löfdahl CG, Larsson P, Lötvall J: Bronchodilation by an inhaled VPAC(2) receptor agonist in patients with stable asthma. Thorax 2003, 58:217-21.

doi:10.1186/1465-9921-12-45

Cite this article as: Wu et al.: Prospect of vasoactive intestinal peptide therapy for COPD/PAH and asthma: a review. Respiratory Research 2011 $12: 45$.

\section{Submit your next manuscript to BioMed Central and take full advantage of:}

- Convenient online submission

- Thorough peer review

- No space constraints or color figure charges

- Immediate publication on acceptance

- Inclusion in PubMed, CAS, Scopus and Google Scholar

- Research which is freely available for redistribution

Submit your manuscript at www.biomedcentral.com/submit
Biomed Central 